\title{
STUDENT'S ETHICAL JUDGMENT TOWARDS ACCOUNTING FRAUD: DOES FORENSIC ACCOUNTING COURSE MATTER?
}

\author{
Herlina Rahmawati Dewi \\ Universitas Islam Indonesia \\ herlina.rd@uii.ac.id \\ Mahmudi \\ Universitas Islam Indonesia \\ mahmudi@uii.ac.id \\ Arienda Sausan Sekardevi
Universitas Islam Indonesia
ariendass98@gmail.com
}

Abstrak: Penilaian Etis Mahasiswa Terhadap Kecurangan Akuntansi. Penelitian ini bertujuan untuk mengetahui pengaruh mata kuliah akuntansi (audit) forensik, status sosial ekonomi, kinerja akademik, dan jenis kelamin pada penilaian etis mahasiswa tentang kecurangan akuntansi. Populasi penelitian ini adalah seluruh mahasiswa akuntansi aktif angkatan tahun 2014-2016 di Fakultas Bisnis dan Ekonomi Universitas Islam Indonesia. Penelitian ini menggunakan data dari sampel sebanyak 120 responden yang dikumpulkan menggunakan metode purposive sampling. Teknik analisis data yang digunakan dalam penelitian ini adalah analisis regresi linier berganda. Studi ini menemukan bahwa mata kuliah akuntansi forensik (audit), status sosial ekonomi, dan kinerja akademik memiliki pengaruh positif dan signifikan terhadap penilaian etis mahasiswa tentang kecurangan akuntansi. Sebaliknya, jenis kelamin tidak mempengaruhi penilaian etis mahasiswa tentang kecurangan akuntansi. Hasil penelitian ini memberikan pencerahan bahwa mata kuliah akuntansi forensik memiliki peran yang sangat penting dalam memperbaiki pertimbangan etis mahasiswa terhadap kecurangan akuntansi. Selain itu, mahasiswa dengan kemampuan akademik yang tinggi dan tingat sosial ekonomi yang tinggi cenderung memiliki pertimbangan etika yang lebih baik. Hal ini menunjukkan bahwa kemampuan bernalar yang baik dan rasional serta kecukupan ekonomi dapat menurunkan kecurangan akuntansi.

Kata kunci: mata kuliah akuntansi forensik, status sosial ekonomi, kinerja akademis, jenis kelamin, penilaian etis, kecurangan akuntansi

\begin{abstract}
Student's Ethical Judgment Towards Accounting Fraud. This study aims to determine whether forensic accounting (audit) courses, socioeconomic status, academic performance, and gender affect students' ethical judgments concerning accounting frauds. This study's population was all active accounting students from 2014-2016 at the Faculty of Business and Economics, Universitas Islam Indonesia. This study uses the purposive sampling method and collects the data from 120 respondents. The data analysis technique used in this study is multiple linear regression analysis. This study found that forensic accounting (audit) courses, socioeconomic status, and academic performance positively and significantly influence students' ethical judgments concerning accounting fraud. In contrast, gender did not affect the students' ethical judgments concerning accounting frauds. The results of this study provide insight that forensic accounting course have a very crucial role in improving students' ethical judgment against accounting fraud. In addition, students with high academic abilities and high socioeconomic levels tend to have better ethical judgments. This means that good and rational reasoning ability and economic adequacy can reduce accounting fraud.
\end{abstract}

Keywords: forensic accounting course, socioeconomic status, academic performance, gender, ethical judgment, accounting fraud 


\section{INTRODUCTION}

Fraud is a deviation or illegal act done intentionally for a specific purpose, such as deceiving or giving a false picture to other parties from within or outside the organization. Fraud is designed to benefit both individuals and groups who use opportunities dishonestly, directly, or indirectly harming other parties (Karyono, 2013). Frauds are categorized into three types commonly called Fraud Tree: corruption, assets misappropriation, and fraudulent financial statements (Singleton et al., 2006)

The most famous case related to fraud, especially financial statements, is the Enron case in the 2000s. The United States' largest company committed many frauds, such as falsifying its net profit by hiding debts held where the nominal is very material. Meanwhile, in Indonesia, one of the most exceptional fraud cases is the case of PT. Waskita Karya, a state-owned construction services firm that inflates assets. The previous period's directors were allegedly expected to carry out financial engineering from the 2004-2008 financial year by entering the projected multi-year project revenue in the future as a certain year's revenue. Recent case was also founded in one of the leading state-owned airlines in Indonesia is known for its service performance, PT. Garuda Indonesia
(Aviantara, 2021; Prayoga \& Purwanti, 2020; Rusmana \& Tanjung, 2020). In the consolidated financial statements of PT Garuda Indonesia (Persero) Tbk in 2018, PT Garuda Indonesia committed fraud by accepting compensation profits for the right to install networking and entertainment service equipment on board, as well as content management, from the agreement with PT Mahata Aero Teknologi (Prayoga \& Purwanti, 2020).

By seeing those three cases - Enron, Waskita Karya, and Garuda Indonesia, accounting students are expected to be the next brilliant generation of good accountants or auditors. Besides, accounting students should also follow and obey the high standards of how to be as ethical as possible as expected by the accounting and auditor profession. Ethical behavior is not simply conforming to legal and professional rules; it is a state of mind adhering to unwritten principles and a culture of 'doing the right thing' (Okezie, 2016).

In the wake of the aforementioned accounting frauds, many scholars have argued that ethics education should begin early in an auditor's career, even before they enter the profession. Johari et al. (2018) found an evidence the importance of ethics within the academic curriculum when the research results show the moral intensity and ideologist ethical orientation influences the 


\section{Nominal: Barometer Riset Akuntansi dan Manajemen}

P-ISSN: 2303-2065 E-ISSN: 2502-5430

Volume 10 No 2 (2021)

future auditors' ethical judgments, but not the relativistic ethical orientation. These findings support by several researches which found the differences in ethical judgement between students and practitioners (Barrainkua \& Espinosa-Pike, 2018; Fatmawati et al., 2018; Ismail, 2017). This can be an indicator that further research is still needed in the curriculum development for ethics education, and the factors influencing ethical judgement, especially for accounting students. The result hopefully could be used to train and strengthen students' ethical judgements and narrow the gap between education and the world of practice.

An ethical person must have a high moral level. The Moral Psychologist (Rest, 1986) also established a four-component model, which seeks to explain the aspects of ethical behavior. He summarized that ethical behavior resulted from psychological subprocesses: moral sensitivity (recognition), moral judgment or reasoning, moral motivation, and moral character. According to (Hunt \& Vitell, 1986), ethical judgment is the process of considering several alternatives and choosing the most ethical alternatives.

Several factors influence one's ethical judgment, especially auditors, when they intend to detect frauds. Having the credibility of being a forensic auditor is one of the factors. The main difference between forensic auditors and public auditors is the sense of detecting and investigating fraud problems. The auditors with the forensic capability are expected to detect and discover fraud, especially fraud materiality, more easily than the public auditor. Boritz et al. (2015) found that it would be more effective for the auditors to design audit programs with forensic expertise than public auditors.

Socioeconomic status can be defined as a picture of a person's state regarding socioeconomic aspects, such as income level. Those with high socioeconomic status tend to prefer higher income and higher consumptive behavior (Pradanti \& Prastiwi, 2014). Such behavior may lead to the ignorance of ethical and moral values as it will allow the emergence of living beyond means.

From the perspective of academic performance, Chan and Leung (2006) stated that the ability to recognize ethical issues in a professional scenario does not depend on accounting students' academic achievement. Meanwhile, academic performance is the grades of courses that the students gain as important material for the accountant profession's skills development, such as decision-making.

The last factor is gender. It is undoubtedly true that men and women never have the same perception of things. This difference also applies when a male auditor's sense of fraud is compared with the female 


\section{Nominal: Barometer Riset Akuntansi dan Manajemen}

P-ISSN: 2303-2065 E-ISSN: 2502-5430

Volume 10 No 2 (2021)

counterpart. Owhoso (2002) concluded that one important issue in ethics, business, and psychological research is that women tend to be more ethically reactive (sensitive) than men to recognize, understand, and identify between ethical and unethical events, or seems to have more moral reasoning and moral development than men do. It is supported by Himmah (2013), who found the influence of gender on the accounting students' perceptions of the accountant's and corporate manager's scandals.

This study aims to investigate whether forensic accounting (audit) courses, socioeconomic status, academic performance, and gender influence students' ethical judgment toward accounting fraud? This study tries to shed light on the factors that affect accounting students' ethical judgment regarding fraud cases. Accounting students who will later work as accountants, auditors, or consultants face ethical dilemmas related to accounting fraud they encounter in their work. This study is relevant to the need for accounting education to identify the main factors that affect accountants' ethical sensitivity to fraud cases. The results of this study can be used as a basis for improving the accounting curriculum and teaching approach.

\section{LITERATURE REVIEW}

\section{A. Ethical Judgment}

Ethics is an activity that studies a person's moral norms or the moral norms of a society, questions how to apply these norms to our lives, and questions whether those norms are based on clear and correct reasons (Pohan, 2017). Rest (1986) developed a fourcomponent framework (moral sensitivity, moral judgment, moral motivation, and moral character) to investigate the nature of human systems of moral thought and behavior. Moral refers to the values of society's general principles that are centered on happiness, welfare, security, development, and human justice (Horner, 2003). When dealing with ethical problems, an individual makes ethical judgment after going through three stages, including recognizing ethical problems, making ethical judgments, and formulating behavioral goals (Barnett \& Valentine, 2004).

Ethical judgment leads to judging whether the correct truth of ethical action is like what should be done (Rest, 1983). In other words, ethical judgment involves evaluating the actions of an auditor in determining a decision based on ethical considerations using moral reasoning with the most ethical alternatives based on the public sector accounting code of conduct 
(auditor) according to individual perceptions when being in an ethical dilemma situation.

\section{B. Fraud}

Fraud is a legal term that refers to a deliberate misunderstanding of the truth to manipulate or deceive a company or individual. Fraud is an illegal act. The act is intended to take illicit profits in the form of money, goods or property, services, not paying for services or obtaining goods or services business by bribing officials (Tuanakotta, 2013). According to the Association of Certified Fraud Examiners (ACFE), fraud is "a deception or misrepresentation that an individual or entity makes knowing that misrepresentation could result in some unauthorized benefits to the individual or the entity or some other party" (Bhasin, 2013). Besides that, ACFE classifies accounting fraud into three types: fraudulent financial reporting, asset misappropriation, and corruption (Singleton et al., 2006).

\section{Forensic Accounting (Audit) Courses}

Since Enron's case, the role of a forensic accountant (auditor) is on the rise. The prominent role of being a forensic accountant is to identify the fraud or commonly stated as recognizing a red flag. Specifically, forensic accounting investigations include litigation services related to various situations, including business purchases, the valuation of divorce assets, property damage, loss of income due to misappropriation such as embezzlement and other unlawful acts, tax evasion, and money laundering scheme (Gray, 2008).

Being a forensic accountant (auditor) requires the right and proper education and training. Stated that forensic accountants with appropriate education, training, and experience may support other agencies and departments in charge of compliance, policy, and recovery, audit committees, and audit teams on financial statements to improve their roles and duties (Popoola et al., 2014; Tawfeeq et al., 2013). Forensic accounting courses aim to broaden accounting knowledge to explain the investigative method from an accounting perspective and understand how accounting helps investigation (Alshurafat et al., 2019; Hoque et al., 2013).

Tawfeeq et al. (2013) revealed that forensic accounting influences detecting cases of financial corruption. Forensic expertise usually includes accounting and investigative skills that enable auditors to systematically gather evidence to address specific problems related to possible errors, including fraud, in the appropriate depth level for use in various law fields, including litigation (Verwey \& Asare, 2016). accounting students must take forensic accounting (audit) courses to be a forensic 


\section{Nominal: Barometer Riset Akuntansi dan Manajemen}

P-ISSN: 2303-2065 E-ISSN: 2502-5430

Volume 10 No 2 (2021)

auditor. The course will teach them to see how fraud perpetrators are under pressure to take advantage of certain companies' opportunities (Carpenter et al., 2011). Students who have taken forensic accounting (audit) courses are expected to provide good ethical judgment against fraud cases compared to those who have not taken. From this explanation, this study proposes that forensic accounting (audit) courses have a positive relationship with student's ethical judgment concerning fraud cases.

\section{Socioeconomic Status}

Social and economic status is a measure of determining one's position based on work, income, and membership in social gatherings. According to Prasastianta (2011), socioeconomic status is the position of a person or family in a community life based on monthly income. Economic status can be seen from income adjusted for the basic goods' prices. In conducting fraud, socioeconomic status is considered one of the main external factors. Insufficient income may cause people to commit fraud.

On the other hand, high positions with respected positions and much income can also be a factor that causes an individual to commit fraud as having power and authority may potentially lead to greediness and also a qualified lifestyle. Prasastianta (2011) examines the factors that drive economic behavior, one of which is socioeconomic status. The study results indicate that the higher the socioeconomic status of a person, the more likely to behave consumptively.

Someone can engage in unethical behavior in a different state of socioeconomic status. Caravita et al. (2012) stated that when determining conditions and taking personal choices, socioeconomic factors have been proven to affect moral values and moral processes. The statement was supported by the research results from Prasastianta (2011), showing that the higher the socioeconomic status of a person, the more likely to behave consumptively. It can be related to ethical behavior because usually, someone who has a high socioeconomic status and behaves in a consumptive manner tends to behave unethically. However, Dhull and Kumar (2012) found no significant association between moral judgment and socioeconomic status in general. From this explanation, this study proposed that socioeconomic status has a positive relationship with student's ethical judgments concerning fraud cases.

\section{E. Academic Performance}

One of the benchmarks for academic performance is the cumulative achievement index or usually called GPA. Pascarella and Terenzini (2005) said achievement, as indicated by grades, is the most revealing indicator of a student's intellectual. Trail et al. 


\section{Nominal: Barometer Riset Akuntansi dan Manajemen}

P-ISSN: 2303-2065 E-ISSN: 2502-5430

Volume 10 No 2 (2021)

(2008) also revealed that the cumulative achievement index as a proxy for the students' cognitive abilities is consistent and compatible with the belief that it is the best predictor of academic success. Dhull and Kumar (2012) stated that moral reasoning development, which is determined more or less by heredity, is affected by intelligence. It could then be said that the higher the cumulative achievement index (GPA) obtained by students, the higher the level of intelligence and the more they can think and behave ethically toward something.

Kohlberg's theory (1981) states that people who have higher education levels can understand more complex problems to lead to better moral reasoning levels. The higher level of education here is determined by GPA (Grade Point Average). It is assumed that the higher the students' grades, the higher their understanding of the subjects studied, and vice versa. Then, students who have a high cumulative GPA are expected to understand fraud cases better ethically. Hence, this study expects that academic performance has a positive relationship with student's ethical judgments concerning fraud cases.

\section{F. Gender}

Gender is a research term used to describe differences between men and women from a non-biological perspective, particularly from social, cultural, and psychological perspectives (Angelia, 2013). Gender differences can provide different judgments in seeing unethical situations that occur. During an audit, female and male auditors face a host of ethical problems, from judging the motives and behaviors of management to knowing the atmosphere at the top of a client's organization (Owhoso, 2002). Chung and Monroe (2001) found that female auditors are more accurate than male auditors in performing complex assignments. Those findings are also supported by Mansori et al.'s (2015) research, who found that gender has a positive effect on undergraduate business students' ethical judgment at five State Universities in Malaysia.

Gender is becoming quite an important issue when it relates to judging or assessing something. Women are considered more careful in taking action and avoiding risks that can harm themselves in the long run. Meanwhile, according to Lunsford (2000), men generally focus on rights and rules when evaluating ethical issues while women generally focus on relationships and responsibilities. This difference reflects that different gender results in different ethical judgments, especially women who will perceive more ethically in assessing an unethical behavior. From this explanation, this study proposed that gender has a positive 
relationship with student's ethical judgments concerning fraud cases.

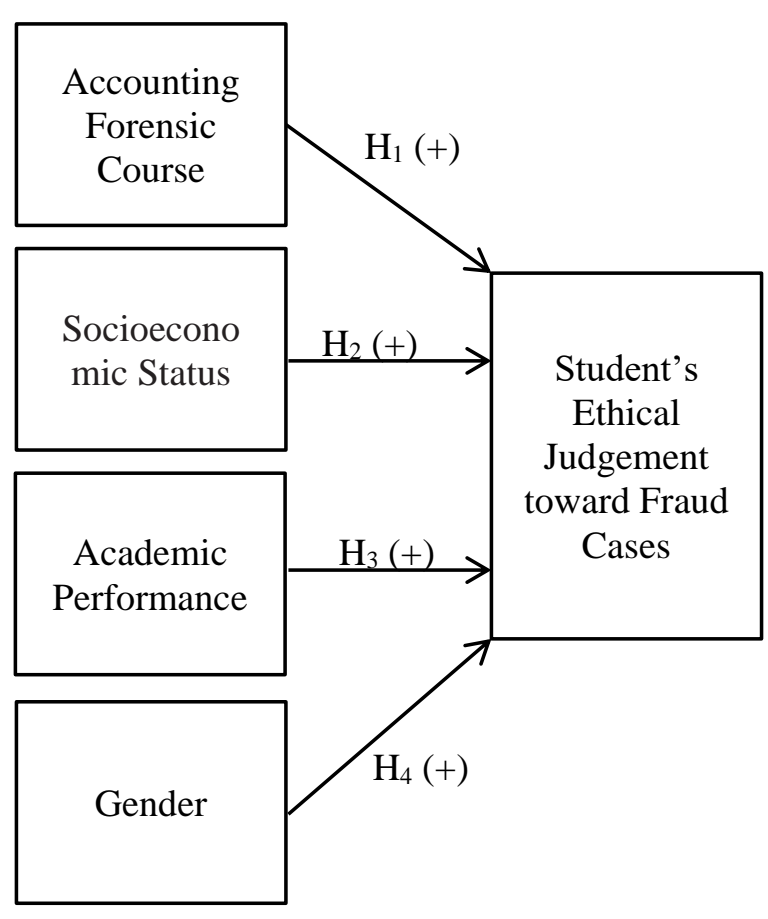

Figure 1: Conceptual Framework

$\mathrm{H}_{1}$ : Forensic accounting (audit) courses have a positive relationship with student's ethical judgment concerning fraud cases.

$\mathrm{H}_{2}$ : Socioeconomic status has a positive relationship with student's ethical judgments concerning fraud cases.

$\mathrm{H}_{3}$ : Academic performance has a positive relationship with student's ethical judgments concerning fraud cases.

$\mathrm{H}_{4}$ : Gender has a positive relationship with student's ethical judgments concerning fraud cases.

\section{RESEARCH METHOD}

\section{A. Population \& Sample}

In this research, the population is the active students of the Accounting
Department, Faculty of Business and Economics, Universitas Islam Indonesia year 2014 to 2016, which is 463 students (Accounting Study Program Universitas Islam Indonesia, 2019). According to Ghozali (2016), in general, the tolerable percentage of errors is $5 \%-10 \%$ due to the results of social research that are difficult to guarantee the accuracy of the data as in specific scientific research. So, the writer uses an error tolerance of $10 \%$.

$$
\mathrm{n}=\frac{463}{1+463 \times 10 \%^{2}}
$$

Based on the above calculations, the results obtained that the minimum number of samples used in this study are 82 accounting students with an error rate of $10 \%$.

Sampling in this study was conducted by purposive sampling. The reason for sampling with this method is because it will only choose samples that meet the criteria. Ghozali (2016) described a purposive sample as selecting participants or sources of data to be used in a study, based on their anticipated richness and relevance of information concerning the study's research questions. The criteria for choosing the samples in this study are as follows:

1. Accounting students, Faculty of Business and Economics, Universitas Islam Indonesia, who still active.

2. Students who are officially registered from 2014, 2015, and 2016. 


\section{B. Data Collection Method}

This research's type of data is quantitative data by processing the questionnaire distributed to the purposive respondents. The source of data in this research is primary data. The primary data are in the form of questionnaires consisting of question items. The primary data are gathered by giving some statements and questions in questionnaires filled out by the respondents. The questionnaire is made online using Google Form. Using an online questionnaire is intended to make the respondents feel free to fill out the questionnaire wherever and whenever as long as it is still in the specified period. This research uses a Likert scale to measure the dependent variable tested. The categories that are used on the Likert scale are 1 (Yes, I definitely would), 2 (I probably would), 3 (I do not know what I would do), 4 (I probably would not), and 5 (no, I definitely would not).

\section{Research Variable}

In this research, there are two variables, the dependent variable, and the independent variable. The variables are as follows:

\section{Dependent Variable (Y)}

The dependent variable of this research is ethical judgment. The students' ethical judgment will be tested with the questionnaire that contains some fraud cases that will lead them to have ethical dilemmas to make the judgment. There will be ten fraud cases and followed by five scales on each case. The first four of the cases are based on those used in the Stanga and Turpen (1991) research, then the next four cases are based on the Betz et al. (1989) research, and the last two cases are based on the O'Leary and Cotter (2000) research. These cases are used to be one of the benchmarks to know someone's ethical judgment. These cases have been selected according to the needs of the authors and also given a slight modification.

\section{Independent Variables}

1. Accounting Forensic (Audit) Courses $\left(\mathrm{X}_{1}\right)$

Forensic accounting education is an important factor in allowing students to learn, observe, and experience these global and local fraud cases (Saito \& Conover, 2016). Accounting (audit) forensic courses can be measured by using a dummy variable. The dummy variable only has 2 (two) values, namely 1 and 0 , and is given the symbol $\mathrm{D}$. In this variable testing, $\mathrm{d}=1$ is for the students that have already taken accounting (audit) forensic courses, and $\mathrm{d}=0$ is for the students that have not taken accounting (audit) forensic courses yet.

\section{Socioeconomic Status $\left(\mathrm{X}_{2}\right)$}

In this research, the socioeconomic status variable will be measured by students' 
monthly allowance and transportation that the students use to go to campus. The allowance reflects the level of consumption made by students who are in line with their parents' income. The means of transportation can show a student's economic level. Students who use private cars to campus have a higher economic level than students who use motorbikes or public transportation. The choices given to respondents are described in Table 1 and Table 2 below:

Table 1: List of Monthly Allowance Choices

\begin{tabular}{cl}
\hline Choice & Monthly Allowance \\
\hline 1 & Less than Rp. 1,000,000 \\
2 & Rp. 1,000,000 - Rp. 1,500,000 \\
3 & Rp. 1,600,000 - Rp. 2,000,000 \\
4 & Rp. 2,100,000 - Rp. 2,500,000 \\
5 & Rp. 2,600,000 - Rp. 3,000,000 \\
6 & More than Rp. 3,000,000 \\
\hline
\end{tabular}

Table 2: Mode of Transportation

\begin{tabular}{cl}
\hline Choice & Transportation \\
\hline 1 & Walking \\
2 & Public transportation \\
3 & Motorcycle \\
4 & Car \\
\hline
\end{tabular}

3. Academic Performance $\left(\mathrm{X}_{3}\right)$

Grade Point Average (GPA) is considered a tool to measure student's abilities during their studies. Trail et al. (2008) said that the achievement index is the best prediction of academic success. In this research, academic performance will be measured by cumulative GPA. The choices of GPA are described in Table 3 below:
Table 3: List of GPA Choices

\begin{tabular}{cc}
\hline Choice & GPA \\
\hline 1 & Less than 2.0 \\
2 & $2.1-2.5$ \\
3 & $2.6-3.0$ \\
4 & $3.1-3.5$ \\
5 & $3.6-4.0$ \\
\hline
\end{tabular}

4. Gender $\left(\mathrm{X}_{4}\right)$

Several studies have shown women have higher ethical attitudes than men (Chung \& Monroe, 2001; Ruegger \& King, 1992). However, the other studies show that men behave ethically than women (Betz et al., 1989; O'Leary \& Cotter, 2000). Meanwhile, some studies show no difference between men and women in their ethical judgment (Hartikainen \& Torstila, 2005; Stanga \& Turpen, 1991). This variable will be tested using a dummy variable, $\mathrm{d}=1$ for males and $\mathrm{d}=0$ for females.

\section{Data Analysis Technique}

This study uses multiple linear regression analysis techniques to determine each independent variable's effect on the dependent variable and uses the SPSS application $21^{\text {st }}$ edition as a statistical tool. Before calculating regression analysis, this study employed validity and reliability test and classical assumption test.

\section{Validity Test}

A validity test is a measure that shows the extent to which the measuring instrument can measure what to be measured. A validity test is used to determine the validity of the 


\section{Nominal: Barometer Riset Akuntansi dan Manajemen \\ P-ISSN: 2303-2065 E-ISSN: 2502-5430 \\ Volume 10 No 2 (2021)}

questionnaire distributed to respondents. This test is carried out to check the questionnaire's statements' validity, whether the statement can reveal something measured by the questionnaire. A questionnaire is valid if the questionnaire's question can reveal something that the research problem needs (Ghozali, 2016). If $\mathrm{r}$ table $<\mathrm{r}$ count (significance level $=5 \%$ ), it is considered valid and vice versa.

In this study, based on 120 questionnaires collected with a confidence level of $95 \%(\alpha=5 \%)$, it can be determined that the $\mathrm{r}$ table's value using the formula $\mathrm{df}=$ $(\mathrm{n}-\mathrm{k})$ is 0.1779 or 0.178 . Based on Table 4 below, all of the items have a corrected itemtotal correlation greater than the $r$ table. Therefore, it could be concluded that the research instruments were valid.

Table 4: Validity Test

\begin{tabular}{lcccc}
\hline Variable & $\begin{array}{c}\text { Question } \\
\text { Code }\end{array}$ & $\begin{array}{c}\text { Corrected } \\
\text { Item- Total } \\
\text { Correlation }\end{array}$ & $\begin{array}{c}\text { r- } \\
\text { table }\end{array}$ & Expl. \\
\hline \multirow{6}{*}{ Ethical } & EJ1 & 0.565 & 0.178 & Valid \\
& EJ2 & 0.608 & 0.178 & Valid \\
Judgment & EJ3 & 0.673 & 0.178 & Valid \\
& EJ4 & 0.610 & 0.178 & Valid \\
& EJ5 & 0.445 & 0.178 & Valid \\
& EJ6 & 0.631 & 0.178 & Valid \\
& EJ7 & 0.414 & 0.178 & Valid \\
& EJ8 & 0.554 & 0.178 & Valid \\
\hline
\end{tabular}

\section{Reliability Test}

Ghozali (2016) stated that reliability is a tool to measure a questionnaire, an indicator of a variable or constructs. A questionnaire can be reliable or reliable if the respondent's answers to the questionnaire questions are consistent or stable from time to time if only the variable gives a Cronbach alpha value of more than 0.6. Such value is the minimum value of each variable to be said reliable. Reliability testing is done by calculating the correlation of each statement on each variable with a total score. So, the closer the coefficient number is, the more reliable the statement item is.

The following are the results of the reliability test:

Table 5: Reliability Test

\begin{tabular}{cccc}
\hline Variable & $\begin{array}{c}\text { Cronbach's } \\
\text { Alpha }\end{array}$ & $\begin{array}{c}\text { Coefficient } \\
\text { Standard }\end{array}$ & Expl. \\
\hline $\begin{array}{c}\text { Ethical } \\
\text { Judgment }\end{array}$ & 0.891 & 0.60 & Reliable \\
\hline
\end{tabular}

Based on Table 5, the research instrument used in this study is reliable because the Cronbach's alpha coefficient is greater than 0.60 . Therefore, it could be concluded that this study could use all the question items as instrument.

\section{Classical Assumption Test}

The classical assumption test is conducted to test the quality of the data. This test aims to test the accuracy in estimation, consistency, and inconsistency of the proposed regression model. This research employs three types of classical assumption tests: the normality test, the multicollinearity test, the heteroscedasticity test. The results of 
classical assumption tests show that all the classical assumptions are fulfilled.

\section{Multiple Linear Regression Analysis}

The analysis used in this study is multiple linear regression, that is, examining the effect of accounting (audit) forensic courses, socioeconomic status, academic performance, and gender on student's ethical judgment concerning fraud cases. In other words, multiple regression analysis perceives the effect of independent variables on the dependent variable (Ghozali, 2016). The general form of multiple linear regression models with $\mathrm{p}$ independent variables is seen in the following equation:

$$
\begin{gathered}
\mathrm{Y}=\mathrm{a}+\mathrm{b}_{1} \text { Forensic }+\mathrm{b}_{2} \text { Academic }+ \\
\mathrm{b}_{3} \text { SocioEcon }+\mathrm{b}_{4} \text { Gender }+\mathrm{e}
\end{gathered}
$$

The data analysis method used to test the four hypotheses about the factors that affect students' ethical judgments regarding fraud cases is t-test with the sig level of 0.05 . The objective of the t-test is to test the regression coefficient individually (partial) of the independent variable on the dependent variable.

\section{RESULT AND DISCUSSION}

\section{A. Data Collection Result}

The primary data in this study were obtained through online questionnaires using Google Form with the link of
https://forms.gle/5XFHYikWToP4uNZu5.

The link was shared with the active accounting students of UII from the year 2014 to 2016. However, only 155 respondents submitted the questionnaires. The researcher used 120 of the submitted questionnaires because the rest are incomplete. There are describe in Table 6 below:

Table 6: Questionnaires Distribution

\begin{tabular}{lc}
\hline Explanation & Amount \\
\hline Questionnaires distributed & 463 \\
Questionnaires returned & 155 \\
Incomplete questionnaires & $(35)$ \\
Questionnaires used & 120 \\
\hline
\end{tabular}

\section{B. Data Description}

Based on Table 7, there are three categories based on the batch. There are 20 respondents from the 2014 intake, 38 respondents from the 2015 intake, and 62 respondents from the 2016 intake. The number of male respondents is 40 respondents, or $33.3 \%$ of the total sample of 100 respondents. The female respondents are 80 respondents or $66.7 \%$ of the total respondents. There are 65 students or $54.2 \%$ of the total respondents who have already taken the forensic accounting (audit) courses, and there are 55 students or $45.8 \%$ of the total respondents who have not yet taken the forensic accounting (audit) courses. 
Table 7: Profile of Respondent

\begin{tabular}{|c|c|c|}
\hline Criteria & Freq & Percentage \\
\hline \multicolumn{3}{|l|}{ Year } \\
\hline 2014 & 20 & $16.7 \%$ \\
\hline 2015 & 38 & $31.7 \%$ \\
\hline 2016 & 62 & $51.6 \%$ \\
\hline \multicolumn{3}{|c|}{ Has Taken Forensic Accounting (Audit) } \\
\hline \multicolumn{3}{|c|}{ Courses } \\
\hline Yes & 65 & $54.2 \%$ \\
\hline No. & 55 & $45.8 \%$ \\
\hline \multicolumn{3}{|c|}{ Monthly Allowances (in Rp000) } \\
\hline Less than Rp1,000 & 6 & $5 \%$ \\
\hline Rp1,000 - Rp1,500 & 30 & $25 \%$ \\
\hline Rp1,600 - Rp2,000 & 32 & $26.7 \%$ \\
\hline $\mathrm{Rp} 2,100$ - Rp2,500 & 27 & $22.5 \%$ \\
\hline $\mathrm{Rp} 2,600$ - Rp3,000 & 13 & $10.8 \%$ \\
\hline More than $\mathrm{Rp} 3,000$ & 12 & $10 \%$ \\
\hline \multicolumn{3}{|l|}{ Transportation } \\
\hline Walking & 20 & $16.7 \%$ \\
\hline Public transportation & 0 & $0 \%$ \\
\hline Motorcycle & 82 & $68.3 \%$ \\
\hline Car & 18 & $15 \%$ \\
\hline \multicolumn{3}{|l|}{$G P A$} \\
\hline Less than 2.0 & 0 & $0 \%$ \\
\hline $2.10-2.50$ & 0 & $0 \%$ \\
\hline $2.60-3.00$ & 6 & $5 \%$ \\
\hline $3.10-3.50$ & 40 & $33.3 \%$ \\
\hline $3.60-4.00$ & 74 & $61.7 \%$ \\
\hline \multicolumn{3}{|l|}{ Gender } \\
\hline Male & 40 & $33.3 \%$ \\
\hline Female & 80 & $66.7 \%$ \\
\hline Total & 120 & $100 \%$ \\
\hline
\end{tabular}

Monthly allowances and the transportation used to go to campus become the proxy to measure the respondent's socioeconomic status. Table 7 displays that the highest percentage of monthly allowance is on the amount of IDR 1.6-2 million, and the lowest one is on the amount of fewer than 1 million rupiahs. There are 20 respondents or $16.7 \%$ of the total respondents who go to campus on foot, 0 respondents using public transportation to go to campus, and 82 respondents or $68.3 \%$ of the total respondents that use a motorcycle to go to campus, and the last, there are 18 respondents or $15 \%$ of the total respondents who use a car to go to campus.

GPA measures academic performance. Table 7 shows us the respondent's profiles based on their GPA. There are no respondents with a GPA less than 2.50; $5 \%$ of respondents have a GPA between 2.60 and 3.00. Forty respondents (33.3\%) have a GPA between 3.00 and 3.50 , and the rest, 74 respondents $(61.7 \%)$, have a GPA of $3.60-$ 4.00 .

\section{Descriptive Statistics Test}

Descriptive statistic analysis is used to describe the state of the research variables statistically. This study uses the minimum and maximum, the mean, and the standard deviation values to describe each variable's statistical description. The following table 8 is the result of descriptive statistical analysis:

Table 8: Descriptive Statistics

\begin{tabular}{lcccc}
\hline \multicolumn{1}{c}{ Variable } & Min. & Max. & Mean & $\begin{array}{c}\text { Std. } \\
\text { Deviation }\end{array}$ \\
\hline $\begin{array}{l}\text { Forensic } \\
\begin{array}{l}\text { Accounting } \\
\text { Audit) }\end{array}\end{array}$ & 0 & 1 & 0.54 & 0.500 \\
$\begin{array}{l}\text { Courses } \\
\text { Socioeconomic }\end{array}$ & 4 & 10 & 6.21 & 1.655 \\
$\begin{array}{l}\text { Status } \\
\text { Academic }\end{array}$ & 3 & 5 & 4.57 & 0.590 \\
$\begin{array}{l}\text { Performance } \\
\text { Gender }\end{array}$ & 0 & 1 & 0.33 & 0.473 \\
$\begin{array}{l}\text { Ethical } \\
\text { Judgment }\end{array}$ & 23 & 40 & 35.25 & 4.911 \\
\hline
\end{tabular}




\section{Nominal: Barometer Riset Akuntansi dan Manajemen \\ P-ISSN: 2303-2065 E-ISSN: 2502-5430 \\ Volume 10 No 2 (2021)}

From the results of the data analysis above, each variable could be described as follows:

1. The forensic accounting (audit) courses variable has a minimum value of 0 , which is the lowest rate, and a maximum value of 1 , the respondents' highest rate. This variable's mean value is 0.54 , which means that most respondents had taken the courses. The forensic accounting (audit) courses' standard deviation value equals 0.500 , which means the size of the data distribution from the forensic accounting (audit) courses is 0.500 from 120 respondents.

2. The Socioeconomic Status variable has a minimum value of 4 , which is the lowest rate and has a maximum value of 10 , the respondents' highest rate. This variable's mean value is 6.21 , which means that the respondents' most answers are on the medium to a high socioeconomic status. The standard deviation value of Socioeconomic Status equals 1.655, which means the size of the data distribution from Socioeconomic Status is 1.655 from 120 respondents.

3. The academic performance variable has a minimum value of 3 , which is the lowest rate, and has a maximum value of 5 , the respondents' highest rate. This variable's mean value is 4.57 , which means most respondents' answers are on a good GPA. Academic performance's standard 
Based on the results of the analysis above, the regression model/equation used as

follows:

$Y=20.669+2.177 X_{1}+0.530 X_{2}+2.288 X_{3}$

$$
-1.014 X_{4}
$$

The interpretation of the equation is as follows:

1. A constant value of 20.669 indicates that if all the independent variables equal zero, the ethical judgment level equals 20.669 units.

2. The forensic accounting courses $\left(X_{1}\right)$ regression coefficient value is 2.177 with a positive direction. It means that for every 1 unit increase in forensic accounting, then ethical judgment would also increase by 2.177 units.

3. The socioeconomic status $\left(\mathrm{X}_{2}\right)$ regression coefficient value is 0.530 with a positive direction. It means that for every 1 unit increase in socioeconomic status, then ethical judgment would increase by 0.530 units.

4. The academic performance $\left(\mathrm{X}_{3}\right)$ regression coefficient value is 2.288 with a positive direction. It means that for every 1 unit increase in academic performance, then ethical judgment would also increase by 2.288 units.

\section{Coefficient of Determination (Adjusted $\left.\mathbf{R}^{2}\right)$ \\ The coefficient of determination is used} to determine the close relationship between the independent and dependent variables. The value of $R^{2}$ lies between 0 to $1\left(0 \leq R^{2} \leq\right.$ 1). The purpose of calculating the coefficient of determination is to determine the independent variable's effect on the dependent variable.

Table 9 shows that the adjusted $\mathrm{R}^{2}$ value is 0.133 , which means that gender, forensic accounting, socioeconomic status, and academic performance could only explain the ethical judgment by $13.3 \%$ after adjusting for the sample and independent variables. The remaining $86.7 \%$ is explained by other variables excluded in this current study.

\section{Result of Partial test (T-Test)}

Hypothesis testing is done using a t-test. This test aims to examine the effect of independent variables (forensic accounting (audit), socioeconomic status, academic performance, and gender) separately on the dependent variable (student's ethical judgment). The influence is seen from the level of significance of the individual independent variables on the dependent variable, assuming other independent variables are of constant value. This test employs a significance level $(\alpha)$ of 5\%. Table 


\section{Nominal: Barometer Riset Akuntansi dan Manajemen}

P-ISSN: 2303-2065 E-ISSN: 2502-5430

Volume 10 No 2 (2021)

9 shows the results of the t-test and its interpretation.

Table 10. Summary of Hypothesis Test Results

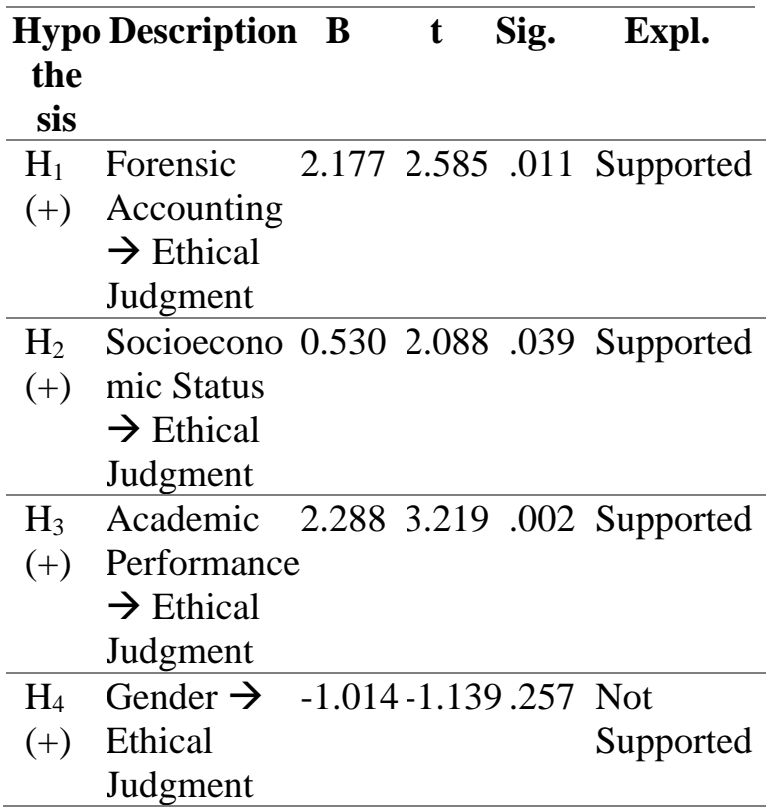

\section{Analysis and Discussion}

The results of hypothesis testing in Table 10 shows that the forensic accounting (audit) courses have a significant level of $0.011<$ 0.05 and t count $2.585>\mathrm{t}$ table 1.980 from the research that involved 120 students. This value means a significant positive relationship between forensic accounting (audit) courses and students' ethical judgment. So, it can be concluded that $\mathrm{H}_{1}$, with the statement of forensic accounting (audit) courses, has a positive relationship with student's ethical judgment concerning fraud cases is accepted, or it can be said that the first hypothesis is supported.

Based on the results above, this research has consistent results with the previous research by Bhasin (2013) that stated there is the influence of having forensic ability in detecting economic and financial fraud. It is in line with Universitas Islam Indonesia's goals that implement forensic accounting (audit) courses; that is, the students are expected to have more insight and knowledge about the real situation in the working world through forensic accounting (audit). American Institute of Certified Public Accountants (AICPA), as cited in (Alshurafat et al., 2019), stated that a forensic accounting program in a college aims to prepare the students to become good forensic accountants.

All of the cases in this research are about the examples of fraud cases that commonly happen to evaluate students' ethical judgment in Universitas Islam Indonesia that have already taken the forensic accounting (audit) courses and the students who have not taken. It could be concluded that Universitas Islam Indonesia has successfully implemented the courses for their accounting students in the Faculty of Business and Economics. The students who have already taken the forensic accounting (audit) courses would be more sensitive as future auditors and accountants to judge the fraud cases provided in this research.

Moreover, this research result is consistent with the previous research by Saito and Conover (2016). They found that 


\section{Nominal: Barometer Riset Akuntansi dan Manajemen}

P-ISSN: 2303-2065 E-ISSN: 2502-5430

Volume 10 No 2 (2021)

students could learn and experience such global fraud cases by having forensic accounting education.

The hypothesis testing results in Table 13 show that socioeconomic status has a significant level of $0.039>0.05$ and $t$ count $2.088>\mathrm{t}$ table 1.980 from the research that involved 120 students. This value means a positive and significant relationship between socioeconomic status and a student's ethical judgment. So it can be concluded that $\mathrm{H}_{2}$, saying that socioeconomic status has a relationship with student's ethical judgment concerning fraud cases, is accepted, or it can be said that the second hypothesis is supported.

Prasastianta (2011) stated people with high socioeconomic status tend to behave more consumptively, which means that the students with higher socioeconomic status tend to behave more ethically when they encounter some unethical situations. In other words, those with lower socioeconomic status tend to behave unethically. Khanifah et al. (2019) predicted that the likelihood of unethical behavior in a state of different socioeconomic status might occur. However, this research has results inversely; economic status does not affect students' ethical perception.

This research corroborates Haidt et al. (1993) found that people with low socioeconomic status are considered disrespectful. It could happen because they live in a situation where they lack sufficient material support. Thus, it makes sense when people with low socioeconomic status tend to have unethical behavior when faced with some unethical situation and if the situations give them the chance to commit fraud.

The results of hypothesis testing in Table 13 shows that academic performance has a significant level of $0.002<0.05$ and $t$ count $3.219>\mathrm{t}$ table 1.980 from the research that involved 120 students. This value means that there is a significant positive relationship between academic performance and student's ethical judgment. So it can be concluded that the third hypothesis $\left(\mathrm{H}_{3}\right)$ : academic performance has a relationship with students' ethical judgment concerning fraud cases, is supported.

Based on the result above, this research has consistent results with Kohlberg's theory (1981). Besides, this research corroborates Dhull and Kumar (2012) that the students owned higher moral reasoning with high intelligence levels not to accept the unethical situation in some moral dilemmas.

The higher level of education in this research is predicted with the level of students' GPA. The research found a significant positive relationship, which means the higher GPA of the students, they tend to be more ethically than the others. 
The hypothesis testing results in Table 13 show that gender has a significant level of $0.257>0.05 \mathrm{f}$ and $\mathrm{t}$ count $-1.139<\mathrm{t}$ table 1.980 from the research that involved 120 students. This value means that there is no significant relationship between gender and student's ethical judgment. So it can be concluded that hypothesis four $\left(\mathrm{H}_{4}\right)$ which states that gender has a relationship with students' ethical judgment concerning fraud cases is not supported.

The reason why gender does not influence the ethical judgment concerning fraud cases is men and women have the same opportunities in carrying out their responsibilities and achievements as an accountant and auditor. Differences in gender roles in making a decision could be overcome by carrying out a profession following professional standards or ethical codes so that professionalism can build public confidence in the quality of services provided. Thus, this study's results similar to Stanga \& Turpen (1991), who found that gender did not explain the variation or differences in people's ethical judgment.

\section{CONCLUSION}

\section{A. Conclusion}

This study was conducted to examine the influence of forensic accounting (audit) courses, socioeconomic status, academic performance, and gender on the students' ethical judgment concerning accounting fraud. Based on the results of data analysis and the discussion described in the previous chapter, it could be concluded that the forensic accounting (audit) courses, socioeconomic status, and academic performance have a significant positive influence on students' ethical judgment. Meanwhile, the students that have not yet taken the forensic accounting (audit) courses, have low socioeconomic status, and have low academic performance will also have bad ethical judgment toward accounting fraud. However, it fails to influence the students' ethical judgment.

This study has some limitations. First, it has only used the specific samples of Universitas Islam Indonesia students. Therefore, it could not be used as generalized. Second, there are some invalid answers from the submitted questionnaires. Out of 155 respondents, only 120 questionnaires could be used for the research data. It because 35 respondents made mistakes and did not fill out the questionnaire completely.

\section{B. Recommendation}

Based on the conclusions above, there are a few suggestions for future researchers who intend to conduct studies on the factors affecting student's ethical judgment: 
1. Accounting students should improve their knowledge, understanding, experience, and expertise in the field of accounting, especially forensic accounting (audit). Furthermore, they are expected to apply ethical and moral values in carrying out their professional work and are also expected to be more sensitive to accounting fraud cases.

2. Future studies should add other relevant variables that can influence Ethical Judgment and add data collection methods besides the questionnaire method so that data generated represents respondents' responses and can avoid bias due to a limited choice of answers.

3. Future studies should expand the population, such as comparing students at two or more universities and increase the number of samples used to gain a more representative picture.

\section{REFERENCES}

Alshurafat, H., Beattie, C., Jones, G., \& Sands, J. S. (2019). Forensic Accounting Core and Interdisciplinary Curricula Components in Australian Universities: Analysis of Websites. Journal of Forensic and Investigative Accounting, 11(2), 353-365. https://www.researchgate.net/publicatio $\mathrm{n} / 338682611$

Aviantara, R. (2021). Scoring The Financial Distress and The Financial Statement Fraud of Garuda Indonesia With «DDCC» As The Financial Solutions. Journal of Modelling in Management.
https://doi.org/10.1108/JM2-01-2020-

0017

Barnett, T., \& Valentine, S. (2004). Issue contingencies and marketers' recognition of ethical issues, ethical judgments and behavioral intentions. Journal of Business Research, 57(4), 338-346.

https://doi.org/10.1016/S01482963(02)00365-X

Barrainkua, I., \& Espinosa-Pike, M. (2018). The Influence of Auditors' Professionalism On Ethical Judgement: Differences Among Practitioners and Postgraduate Students. Revista de Contabilidad-Spanish Accounting Review, 21(2), 176-187. https://doi.org/10.1016/j.rcsar.2017.07. 001

Betz, M., O'Connell, L., \& Shepard, J. M. (1989). Gender differences in proclivity for unethical behavior. Journal of Business Ethics, 8(5), 321-324. https://doi.org/10.1007/BF00381722

Bhasin, M. L. (2013). Corporate Accounting Fraud: A Case Study of Satyam Computers Limited. Open Journal of Accounting, 2, 26-38. https://ssrn.com/abstract $=2676467$

Boritz, J. E., Kochetova-Kozloski, N., \& Robinson, L. (2015). Are fraud specialists relatively more effective than auditors at modifying audit programs in the presence of fraud risk? The Accounting Review, 90(3), 881-915. https://doi.org/10.2308/accr-50911

Caravita, S. C. S., Giardino, S., Lenzi, L., Salvaterra, M., \& Antonietti, A. (2012). Socio-economic Factors Related to Moral Reasoning in Childhood and Adolescence: The Missing Link between Brain and Behavior. Frontiers in Human Neuroscience, 6(262), 1-14. https://doi.org/10.3389/fnhum.2012.00 262 
Carpenter, T. D., Durtschi, C., \& Gaynor, L. M. (2011). The Incremental Benefits of A Forensic Accounting Course on Skepticism and Fraud-Related Judgments. Issues in Accounting Education, 26(1), 1-21. https://doi.org/10.2308/iace.2011.26.1. 1

Chan, S. Y. S., \& Leung, P. (2006). The Effects of Accounting Students' Ethical Reasoning and Personal Factors on Their Ethical Sensitivity. Managerial Auditing Journal, 21(4), 436-457. https://doi.org/10.1108/0268690061066 1432

Chung, J., \& Monroe, G. S. (2001). A Research Note on the Effects of Gender and Task Complexity on an Audit Judgment. Behavioral Research in Accounting, 13(1), 111-125. https://doi.org/10.2308/bria.2001.13.1. 111

Dhull, N., \& Kumar, I. (2012). Development of Moral Reasoning in the Context of Intelligence and Socio-Economic Status Following Value Clarification. Journal of Education and Practice, 3(14), 3338 .

Fatmawati, D., Mustikarini, A., \& Puspita Fransiska, I. (2018). Does Accounting Education Affect Professional Skepticism and Audit Judgment? (Adakah Pendidikan Perakaunan Mempengaruhi Kecurigaan Profesional dan Penghakiman Audit?). Jurnal Pengurusan, 52(0), 221-233. https://doi.org/10.17576/pengurusan2018-52-18

Ghozali, I. (2016). Desain Penelitian Kuantitatif dan Kualitatif untuk Akuntansi, Bisnis, dan Ilmu Sosial Lainnya. Yoga Pratama.

Gray, D. (2008). Forensic Accounting and Auditing: Compared and Contrasted to Traditional Accounting and Auditing.
American Journal of Business Education, 1(2), 115-126. https://eric.ed.gov/?id=EJ1052569

Haidt, J., Koller, S. H., \& Dias, M. G. (1993). Affect, Culture, and Morality, or Is It Wrong to Eat Your Dog? Journal of Personality and Social Psychology, 65(4), 613-628. https://doi.org/10.1037/00223514.65.4.613

Hartikainen, O., \& Torstila, S. (2005). JobRelated Ethical Judgment in the Finance Profession. Journal of Applied Finance (JAF), 14(1), 62-76. https://ssrn.com/abstract=561006

Himmah, E. F. (2013). Persepsi Etis Mahasiswa Akuntansi mengenai Skandal Etis Auditor dan Corporate Manager. Jurnal Akuntansi Multiparadigma, 4(1), 26-39. https://doi.org/10.18202/jamal.2013.04. 7180

Hoque, N., Khan, M. A., \& Mowla, M. M. (2013). Organisational Culture: Features and Framework from Islamic Perspective. Humanomics, 29(3), 202$219 . \quad$ https://doi.org/10.1108/H-062013-0040

Horner, J. (2003). Morality, Ethics, and Law: Introductory Concepts. Seminars in Speech and Language, 24(4), 263-274. https://doi.org/10.1055/s-2004-815580

Hunt, S. D., \& Vitell, S. (1986). A General Theory of Marketing Ethics. Journal of Macromarketing, 5-16. https://doi.org/10.1177/0276146786006 00103

Ismail, S. (2017). Ethical Judgment and Ethical Ideology of Accounting Professionals and Accounting Students. Asian Journal of Accounting Perspectives, 10(1), 99-113. https://doi.org/10.22452/ajap.vol10no.6 
Johari, R. J., Yazid, A. S., \& Salleh, F. (2018). An Empirical Examination of Undergraduate Accounting Students' Ethical Judgment: Malaysia Evidence. International Journal of Academic Research in Business and Social Sciences, 8(12), 669-681. https://doi.org/10.6007/IJARBSS/v8i12/5064

Karyono. (2013). Forensic Fraud (D. Hardjono (ed.)). CV. ANDI. https://openlibrary.telkomuniversity.ac. $\mathrm{id} /$ pustaka/30487/forensic-fraud.html

Khanifah, K., Isgiyarta, J., Lestari, I., \& Udin, U. (2019). The Effect of Gender, Locus of Control, Love of Money, and Economic Status on Students' Ethical Perception. International Journal of Higher Education, 8(5). https://doi.org/10.5430/ijhe.v8n5p168

Kohlberg, L. (1981). Essays on Moral Development: The Philosophy of Moral Development. Harper \& Row.

Lunsford, D. L. (2000). Ethical Judgements: Does Gender Matter? Teaching Business Ethics, 4(1), 1-22. https://doi.org/10.1023/A:10098395174 82

Mansori, S., Rezaee, Z., Homayoun, S., \& Noghondari, A. T. (2015). Do Individual Traits Associate with Ethical Judgment? Journal of Management and Sustainability, $\quad 5(3), \quad 85$. https://doi.org/10.5539/jms.v5n3p85

O'Leary, C., \& Cotter, D. (2000). The Ethics of Final Year Accountancy Students: An International Comparison. Managerial Auditing Journal, 15(3), 108-115.

https://doi.org/10.1108/0268690001031 9366

Okezie, S. O. (2016). Auditing and Ethical Sensitivity: Resolving the Dilemma. European Journal of Accounting,
Auditing and Finance Research, 4(4), 25-36.

Owhoso, V. (2002). Mitigating Genderspecific Superior Ethical Sensitivity When Assessing Likelihood Of Fraud Risk. Journal of Managerial Issues, XIV(3), 360-374. https://www.jstor.org/stable/40604396

Pascarella, E. T., \& Terenzini, P. T. (2005). How College Affects Students: A Third Decade of Research (Vol. 2). JosseyBass, An Imprint of Wiley. http://www.josseybass.com

Pohan, H. T. (2017). Persepsi Mahasiswa Tentang Nilai-Nilai Etika Dalam Penyajian Pelaporan Keuangan Perusahaan Yang Bertanggung Jawab. Media Ekonomi, 20(2), 13. https://doi.org/10.25105/me.v20i2.781

Popoola, O. M. J., Che-Ahmad, A., \& Samsudin, R. S. (2014). Forensic Accounting Knowledge and Mindset on Task Performance Fraud Risk Assessment. International Journal of Business and Management, 9(9). https://ssrn.com/abstract $=2654800$

Pradanti, N. R., \& Prastiwi, A. (2014). Analisis Pengaruh Love Of Money Terhadap Persepsi Etis Mahasiswa Akuntansi [Universitas Diponegoro]. http://eprints.undip.ac.id/43623/

Prasastianta, D. (2011). Pengaruh Minat Pada Pelajaran Ekonomi, Status Sosial Ekonomi Orang Tua, Pengetahuan Ekonomi Dan Rasionalitas Ekonomi Terhadap Perilaku Ekonomi. Universitas Negeri Makassar.

Prayoga, M. H., \& Purwanti, D. (2020). Case Analysis Of Revenue Recognition Fraud Of PT. Garuda Indonesia (Persero) Tbk In 2018. Riset, 2(2), 289306. https://doi.org/10.35212/riset.v2i2.63 
Rest, J. R. (1983). Morality. In P.H. Mussen (Ed.). Handbook of child psychology: (4th ed.) Vol. 3: Cognitive Development (In J.H. Flavell \& E.M. Markman, Eds.) . In Handbook of child psychology: Vol. 3. Cognitive development. John Wiley.

Rest, J. R. (1986). Moral Development: Advances in Research and Theory. Praeger.

https://repository.library.georgetown.ed u/handle/10822/811393

Ruegger, D., \& King, E. W. (1992). A Study of The Effect of Age and Gender upon Student business ethics. Journal of Business Ethics, 11(3), 179-186. https://doi.org/10.1007/BF00871965

Rusmana, O., \& Tanjung, H. (2020). Identifikasi Kecurangan Laporan Keuangan Dengan Fraud Pentagon Studi Empiris BUMN Terdaftar Di Bursa Efek Indonesia. Jurnal Ekonomi, Bisnis, Dan Akuntansi, 21(4). https://doi.org/10.32424/jeba.v21i4.154 5

Saito, M., \& Conover, T. L. (2016). Global Case Studies in Forensic Accounting Education: The Case of Audit Failures. The Journal of Global Business Management, $12(1), \quad 183$. http://www.jgbm.org/page/18 Masako SAITO.pdf

Singleton, T. W., Singleton, A. J., Bologna, G. J., \& Lindquist, R. J. (2006). Fraud Auditing and Forensic Accounting (3rd ed.). John Wiley \& Sons, Inc.

Stanga, K. G., \& Turpen, R. A. (1991). Ethical judgments on selected accounting issues: An empirical study. Journal of Business Ethics, 10(10), 739-747. https://doi.org/10.1007/BF00705708

Tawfeeq, T., Alabdullah, Y., Yahya, S., Mohammad, M., Alfadhl, A., Ala, \&, \&
Rabi, M. A. (2013). The Role of Forensic Accounting in Reducing Financial Corruption: A Study in Iraq Renewable energy supply chain View project Social Enterprises Performance View project The Role of Forensic Accounting in Reducing Financial Corruption: A Study in Iraq. Article in International Journal of Business and Management, https://doi.org/10.5539/ijbm.v9n1p26

Trail, C., Reiter, H. I., Bridge, M., Stefanowska, P., Schmuck, M., \& Norman, G. (2008). Impact of field of study, college and year on calculation of cumulative grade point average. Advances in Health Sciences Education, 13(3), 253-261. https://doi.org/10.1007/s10459-0069037-z

Tuanakotta, T. M. (2013). Audit Berbasis ISA (international Standards on Auditing). Salemba Empat.

Verwey, I., \& Asare, S. K. (2016). The Effect of Forensic Expertise and Time Pressure on Fraud Risk Assessment and Responsiveness. SSRN Electronic Journal. https://doi.org/10.2139/ssrn.2864350 